\title{
Resistance of soybean genotypes to Sclerotinia sclerotiorum isolates in different incubation environments
}

\author{
L.H.S. Castro ${ }^{1}$, A.A. Figueiró ${ }^{2}$, A.P.O. Nogueira ${ }^{3}$, S.J. Clough ${ }^{4}$ and \\ F.C. Juliatti ${ }^{2}$ \\ ${ }^{1}$ Centro de Ciências Agrárias e Engenharias, \\ Universidade Federal do Espírito Santo, Araxá, MG, Brasil \\ ${ }^{2}$ Instituto de Ciências Agrárias, Universidade Federal de Uberlândia, \\ Uberlândia, MG, Brasil \\ ${ }^{3}$ Instituto de Genética e Bioquímica, Universidade Federal de Uberlândia, \\ Uberlândia, MG, Brasil \\ ${ }^{4}$ University of Illinois, Urbana, IL, USA \\ Corresponding author: L.H.S. Castro \\ E-mail: leonardohumbertoagro@hotmail.com
}

Genet. Mol. Res. 15 (4): gmr15049061

Received August 8, 2016

Accepted September 19, 2016

Published November 21, 2016

DOI http://dx.doi.org/10.4238/gmr15049061

Copyright (C) 2016 The Authors. This is an open-access article distributed under the terms of the Creative Commons Attribution ShareAlike (CC BY-SA) 4.0 License.

ABSTRACT. Sclerotinia sclerotiorum is an important soybean
pathogen. The objectives of this study were to evaluate levels of
resistance of soybean genotypes to the fungus, and to determine the
effects of different incubation environments on host resistance and
pathogen aggressiveness. Two experiments were conducted using 103
genotypes from the seed collection of Laboratorio de Desenvolvimento
de Germoplasma, Universidade Federal de Uberlândia (LAGER-UFU).
The first experiment was conducted in a greenhouse, and the second
in a growth chamber. Inoculations were performed by the straw test 
method using two Brazilian isolates of the fungus, one from Uberaba, Minas Gerais, and the other from Jataí, Goiás. The average stem-lesion length $(\mathrm{cm})$ at 5 days post-inoculation was used to determine levels of resistance. Overall, the most resistant genotype was EMGOPA-316, and the most susceptible genotype was LAGER-29. Incubation in a growth chamber and use of the Jataí isolate generated the most reliable data, and multivariate analysis indicated that the genotypes were divergent under the growth chamber conditions. Therefore, when studying host resistance of soybean genotypes to S. sclerotiorum, it is important to use environmental conditions favorable to the fungus and aggressive isolates.

Key words: White mold; Genetic variability; Plant breeding; Inoculation; Host resistance and pathogen aggression; Incubation environments

\section{INTRODUCTION}

White mold disease is caused by the necrotrophic fungus Sclerotinia sclerotiorum (Lib.) de Bary and is of economic importance in many regions of the world. This disease was first identified in Brazil in São Paulo State on a potato farm in 1921 (Chaves, 1964). From there, the disease spread across the country and has been found in the south, southeast, central west, and northeast regions. In an infected field, the damage caused by this fungal pathogen may vary from 30 to $100 \%$ if no preventative measures are adopted (Chaves, 1964; Henning, 2004; Juliatti et al., 2013).

Favorable environmental conditions for infection include high humidity, low temperatures $\left(10^{\circ}-21^{\circ} \mathrm{C}\right)$ and, in some cases, altitudes above $800 \mathrm{~m}$. Another important factor in the control of infection is the wide host range of the fungus, which includes many weeds. For example, crop rotation is more challenging with a pathogen like S. sclerotiorum as it infects many popular dicot crops including soybean, cotton, common bean, potato, tomato, and peas (Juliatti and Juliatti, 2010).

In soybean, infection occurs during the flowering period, as ascospores infect flowers, and detached infected flowers inoculate the leaves, where the mycelium may continue to spread throughout the parts of the plants that are above ground level, including colonization of the pods until the end of the grain-fill period (Juliatti et al., 2015; Furlan, 2015). The management of $S$. sclerotiorum is difficult; it is almost impossible to eradicate contaminated areas, and highly effective control measures have not yet been developed. The current recommendation for control is an integrated management approach, which includes cultural practices, biological agents, chemical sprays, and partially resistant genetic material (Cunha et al., 2010; Bastien et al., 2014).

As with most plant diseases, the best way to control white mold would involve the use of genetically resistant plants. However, currently, there are no known soybean genotypes with $100 \%$ resistance to $S$. sclerotiorum, and soybean breeding for resistance to this pathogen is challenging owing to genetic complexity and low heritability (Hoffman et al., 1998). Only a few genotypes have been identified with enhanced resistance to this fungus, and there is often a poor correlation between resistance as evaluated in a lab or greenhouse, and the actual resistance observed in the field (Hoffman et al., 1998; Kim et al., 2000; Juliatti et al., 2013).

Genetics and Molecular Research 15 (4): gmr15049061 
The objective of this study was to identify additional soybean genotypes with enhanced resistance to $S$. sclerotiorum, which may be of use to producers and scientists in breeding programs. Identification was accomplished through the phenotypic evaluation of resistance under different incubation environments following the inoculation of the plant with two different fungal isolates.

\section{MATERIAL AND METHODS}

\section{Location and time of the experiments}

The experiments were carried out in Laboratório de Micologia e Proteção de Plantas (LAMIP) and in the phytopathology greenhouse at Universidade Federal de Uberlândia (UFU) in Uberlândia, Minas Gerais, Brazil, during 2014 and 2015.

\section{Germplasm and sowing}

The genotypes used in this study included 101 soybean lines developed by Laboratório de Desenvolvimento de Germoplasma of UFU (LAGER-UFU), coded LAGER-03 to LAGER-103. The genealogy of these genotypes is described in Table 1. They originated from double crossovers and the population was obtained by pedigree or genealogical breeding methods. In addition, the resistant genotype EMGOPA-316 (Garcia and Juliatti, 2012) and the highly susceptible genotype M7908RR were utilized as controls (Juliatti et al., 2013)

In the first experiment, the genotypes were sown in 500-mL plastic cups filled with a 1:1 soil:sand mixture. In the second experiment, the genotypes were sown in 72-cell trays

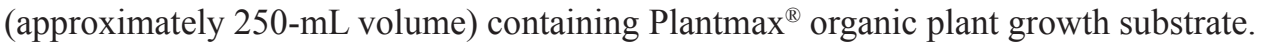

\section{S. sclerotiorum isolate growth, inoculation, and scoring}

The fungal isolates were obtained from sclerotia collected in soybean production fields located in the municipalities of Uberaba in the State of Minas Gerais, and Jataí in the State of Goiás (Garcia and Juliatti, 2012). The sclerotia were disinfested by soaking for $30 \mathrm{~s}$ in alcohol $(50 \% \mathrm{v} / \mathrm{v})$, followed by $30 \mathrm{~s}$ in sodium hypochlorite $(0.5 \% \mathrm{v} / \mathrm{v})$, and were subsequently rinsed three times with sterile distilled water. After this procedure, the sclerotia were incubated on Petri dishes containing potato dextrose agar (PDA) at $22^{\circ} \pm 3^{\circ} \mathrm{C}$ with a photoperiod of $12 \mathrm{~h}$ to encourage myceliogenic germination. The straw test (Petzoldt and Dickson, 1996) was used to inoculate plants that were at the V3-V4 growth stage. After the fungal mycelia had grown across the entire surface of the 90-cm diameter Petri plates (about 4-5 days), $\sim 5-\mathrm{mm}$ diameter discs (obtained using the wide end of a $200-\mu \mathrm{L}$ pipette tip) of PDA containing fungal mycelia were placed securely on a freshly cut stem, with the stem placed into the inoculum plug within the pipette tip. In one experiment, carried out between October and November 2014, the plants were inoculated with each isolate in the Instituto de Ciências Agrárias of UFU greenhouse. The experimental design was randomized blocks with five replicates, with each plot comprised of a plant. In the other experiment, carried out between January to February 2015, the plants were inoculated with the Jataí isolate and incubated within a growth chamber at LAMIPUFU, with a temperature of $22^{\circ} \pm 3^{\circ} \mathrm{C}$ and a 12 -h photoperiod. The experimental design was completely randomized with five replicates, and each plot comprised of a plant.

Genetics and Molecular Research 15 (4): gmr15049061 
Table 1. Genealogy of the genotypes.

\begin{tabular}{|c|c|c|c|}
\hline Genotype & Genealogy & Genotype & Genealogy \\
\hline LAGER-03 & BRS Luziânia RR - Selection 1 & LAGER-54 & F5:6 BRS Luziâna x Potenza \\
\hline LAGER-04 & BRS Luziânia RR - Selection 2 & LAGER-55 & F5:6 Luziânia x Impacta \\
\hline 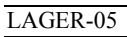 & BRS Luziânia RR - Selection 3 & LAGER-56 & F5:6 Luziânia x Impacta \\
\hline LAGER-06 & BRS Luziânia RR - Selection 4 & LAGER-57 & F5:6 BRS Caiapônia x IAC 100 \\
\hline LAGER-07 & BRS Luziânia RR - Selection 5 & LAGER-58 & F5:6 BRS Caiapônia x IAC 100 \\
\hline LAGER-08 & BRS Luziânia RR - Selection 6 & LAGER-59 & F5:6 BRS Caiapônia x IAC 100 \\
\hline LAGER-09 & Emgopa 316 RR - Selection 1 & LAGER-60 & F5:6 Caiapônia x Potenza \\
\hline LAGER-10 & Emgopa 316 RR - Selection 3 & LAGER-61 & F5:6 Caiapônia x Potenza \\
\hline LAGER-11 & Emgopa 316 RR - Selection 4 & LAGER-62 & F5:6 BRS Caiapônia x IAC 100 \\
\hline LAGER-12 & BRS Caiapônia - Selection & LAGER-63 & F5:6 BRS Caiapônia x IAC 100 \\
\hline LAGER-13 & F5:6 BRS Luziânia x Potenza & LAGER-64 & F5:6 Caiapônia x Potenza \\
\hline LAGER-14 & F5:6 BRS Caiapônia x IAC 100 & LAGER-65 & F5:6 BRS Caiapônia x IAC 100 \\
\hline LAGER-15 & F5:6 BRS Luziâna x Potenza & LAGER-66 & F5:6 BRS Luziâna x Potenza \\
\hline LAGER-16 & F5:6 BRS Luziâna x Potenza & LAGER-67 & F5:6 BRS Caiapônia x IAC 100 \\
\hline LAGER-17 & F5:6 BRS Luziâna x Potenza & LAGER-68 & F5:6 BRS Caiapônia x IAC 100 \\
\hline LAGER-18 & F5:6 BRS Caiapônia x IAC 100 & LAGER-69 & F5:6 BRS Caiapônia x IAC 100 \\
\hline LAGER-19 & F5:6 BRS Caiapônia x IAC 100 & LAGER-70 & F5:6 BRS Caiapônia x IAC 100 \\
\hline LAGER-20 & F5:6 BRS Luziâna x Potenza & LAGER-71 & F5:6 BRS Luziâna x Potenza \\
\hline LAGER-21 & F5:6 BRS Luziâna x Potenza & LAGER-72 & F5:6 BRS Luziâna x Potenza \\
\hline LAGER-22 & F5:6 BRS Luziâna x Potenza & LAGER-73 & F5:6 BRS Caiapônia x IAC 100 \\
\hline LAGER-23 & F5:6 BRS Caiapônia x IAC 100 & LAGER-74 & F5:6 BRS Caiapônia x IAC 100 \\
\hline LAGER-24 & F5:6 BRS Caiapônia x IAC 100 & LAGER-75 & F5:6 BRS Caiapônia x IAC 100 \\
\hline LAGER-25 & F5:6 BRS Caiapônia x IAC 100 & LAGER-76 & F5:6 BRS Caiapônia x IAC 100 \\
\hline LAGER-26 & F5:6 BRS Caiapônia x IAC 100 & LAGER-77 & F5:6 BRS Caiapônia x IAC 100 \\
\hline LAGER-27 & F5:6 BRS Caiapônia x IAC 100 & LAGER-78 & F5:6 BRS Caiapônia x IAC 100 \\
\hline LAGER-28 & F5:6 BRS Caiapônia x IAC 100 & LAGER-79 & F5:6 BRS Caiapônia x IAC 100 \\
\hline LAGER-29 & F5:6 BRS Luziâna x Potenza & LAGER-80 & F5:6 BRS Luziâna x Potenza \\
\hline LAGER-30 & F5:6 BRS Luziâna x Potenza & LAGER-81 & F5:6 Luziânia x Impacta \\
\hline LAGER-31 & F5:6 BRS Luziâna x Potenza & LAGER-82 & F5:6 Luziânia x Impacta \\
\hline LAGER-32 & F5:6 BRS Luziâna x Potenza & LAGER-83 & F5:6 BRS Luziâna x Potenza \\
\hline LAGER-33 & F5:6 BRS Santa Cruz x Potenza & LAGER-84 & F5:6 BRS Luziâna x Potenza \\
\hline LAGER-34 & F5:6 BRS Santa Cruz x Potenza & LAGER-85 & F5:6 Caiapônia x Potenza \\
\hline LAGER-35 & F5:6 BRS Luziâna x Potenza & LAGER-86 & F5:6 BRS Luziâna x Potenza \\
\hline LAGER-36 & F5:6 BRS Luziâna x Potenza & LAGER-87 & F5:6 BRS Luziâna x Potenza \\
\hline LAGER-37 & F5:6 BRS Caiapônia x IAC 100 & LAGER-88 & F5:6 BRS Luziâna x Potenza \\
\hline LAGER-38 & F5:6 BRS Santa Cruz x IAC100 & LAGER-89 & F5:6 BRS Luziâna x Potenza \\
\hline LAGER-39 & F5:6 BRS Santa Cruz x IAC100 & LAGER-90 & F5:6 Caiapônia x Potenza \\
\hline LAGER-40 & F5:6 Luziânia x Impacta & LAGER-91 & F5:6 Caiapônia x IAC100 \\
\hline LAGER-41 & F5:6 Luziânia x Impacta & LAGER-92 & F5:6 Caiapônia x IAC100 \\
\hline LAGER-42 & F5:6 Luziânia x Impacta & LAGER-93 & F4 RC4.12 x MSOY 9350 \\
\hline LAGER-43 & F5:6 BRS Luziâna x Potenza & LAGER-94 & F5:6 Caiapônia x IAC100 \\
\hline LAGER-44 & F5:6 BRS Luziâna x Potenza & LAGER-95 & F5:6 BRS Luziâna x Potenza \\
\hline LAGER-45 & F5:6 BRS Caiapônia x IAC 100 & LAGER-96 & F5:6 BRS Luziâna x Potenza \\
\hline LAGER-46 & F5:6 BRS Caiapônia x IAC 100 & LAGER-97 & F5:6 BRS Luziâna x Potenza \\
\hline LAGER-47 & F5:6 BRS Caiapônia x IAC 100 & LAGER-98 & F5:6 BRS Luziâna x Potenza \\
\hline LAGER-48 & F5:6 Caiapônia x Potenza & LAGER-99 & F5:6 Luziânia x Impacta \\
\hline LAGER-49 & F5:6 Caiapônia x Potenza & LAGER-100 & F5:6 BRS Luziâna x Potenza \\
\hline LAGER-50 & F5:6 Caiapônia x Potenza & LAGER-101 & F5:6 BRS Luziâna x Potenza \\
\hline LAGER-51 & F5:6 BRS Caiapônia x IAC 100 & LAGER-102 & F5:6 BRS Luziâna x Potenza \\
\hline LAGER-52 & F5:6 BRS Caiapônia x IAC 100 & LAGER-103 & F5:6 Caiapônia x IAC100 \\
\hline LAGER-53 & F5:6 Luziânia x Impacta & & \\
\hline
\end{tabular}

To evaluate the degree of disease progression, plants were scored 5 days postinoculation by measuring the average size of the lesion in centimeters (Petzoldt and Dickson, 1996; Singh and Terán, 2008).

Genetics and Molecular Research 15 (4): gmr15049061 


\section{Statistics and genetic parameters}

For the greenhouse study, a joint analysis of the average lesion length $(\mathrm{cm})$ of five replicates from both isolates (Uberaba and Jataí) was performed using analysis of variance $(\mathrm{P}<0.05)$ and the Scott-Knott test $(\mathrm{P}<0.05)$. The genotypes and isolates were considered as fixed effects in the joint analysis statistical model. The residual variants obtained in the individual analyses were verified for the existence of homogeneity by performing a grouped analysis by the range between the biggest and the lowest mean square, adopting a value of 7 as the standard, followed by a Scott-Knott test $(\mathrm{P}<0.05)$. For the growth chamber study, the average lesion length $(\mathrm{cm})$ of five replicates was used in analysis of variance $(\mathrm{P}<0.05)$ and an individual analysis by the Scott-Knott test $(\mathrm{P}<0.05)$.

Genetic parameters associated with lesion length $(\mathrm{cm})$ were analyzed to determine the genotypic coefficient $\left(\mathrm{h}^{2}\right)$, and the range of the genetic variation coefficient was determined by the environmental variation coefficient $(\mathrm{CVg} / \mathrm{CVe})$ for both experiments and isolates.

The genetic parameters of the average lesion length were estimated by analysis of variance:

$$
\begin{gathered}
\hat{\phi}_{g}^{\wedge}=\frac{Q M T-Q M R}{r} \\
H^{2}=\frac{\hat{\phi}_{g}}{Q M T / r}
\end{gathered}
$$

where,: $\hat{\phi}_{g}$ is the quadratic genetic component; $H^{2}$ is the coefficient of genotypic determination; $Q M T$ is the mean square of the treatment (genotype); $Q M R$ is the mean square of the residue; and $r$ is the number of replicates (five).

To verify the genetic divergence of the genotypes, a multivariate analysis was performed on the average lesion length. Data on the average lesion length obtained from the greenhouse and growth chamber experiments were subjected to multivariate analysis. Data were standardized:

$$
x_{i j}=\frac{X_{i j}}{s\left(X_{i j}\right)}
$$

where, $\mathrm{x}_{\mathrm{ij}}$ is the standardized mean of the $i^{i \text { th }}$ genotype of the $j^{\text {th }}$ experiment; $X_{i j}$ is the $i^{\text {th }}$ genotype of the $j^{\text {th }}$ experiment, original data; and $s(X)_{j}$ is the standard deviation.

The dissimilarity measure between the genotypes was obtained by standardized mean Euclidean distance:

$$
d_{i i^{\prime}}=\sqrt{\frac{1}{n} \sum_{j}\left(x_{i j}-x_{i^{\prime} j}\right)^{2}}
$$

where, $d_{i i}$, is the mean Euclidean distance between the $i$ and $i$ ' genotype; $x_{i j}$ is the value of the average lesion size in $i$ genotype; $x_{i j}$ is the value of the average lesion size in $i$ ' genotype; $n$ is the number of variables (number of experiments).

The unweighted pair group method with arithmetic mean (UPGMA) method was used. The tree dendrogram was established by the genotypes with the highest similarity, wherein the

Genetics and Molecular Research 15 (4): gmr15049061 
distance between genotype $k$ and the group formed by the $i$ and $j$ genotypes was given by:

$$
d_{(i j) k}=\frac{d_{i k}+d_{j k}}{2}
$$

Tocher's grouping method was performed using the dissimilarity matrix. The first group consisted of genotypes with low dissimilarity measures. Posteriorly, other genotypes were included in this group by comparing the increase in the average value of the distance within the group and a maximum level allowed predetermined $(\theta)$ of the dissimilarity measure that was found in the set of shorter distances involving each genotype. The inclusion of each genotype was determined by:

$$
\begin{gathered}
\frac{d_{(\text {group }) k}}{n} \leq \theta k \text { genotype is included in the group; and } \\
\frac{d_{(\text {group }) k}}{n}>\theta k \text { genotype is not included. }
\end{gathered}
$$

where $\mathrm{n}=$ number of genotypes from the original group.

The distance between the $k$ genotype and the group formed by the $i$ and $j$ genotype was given by:

$$
d_{(i j) k}=d_{i k}+d_{j k}
$$

All statistical analyses were performed using the program GENES (Cruz, 2013).

\section{RESULTS AND DISCUSSION}

\section{Greenhouse experiment}

In the greenhouse study, the genotypes that showed the highest level of resistance when inoculated with the Uberaba isolate were EMGOPA-316, LAGER-05, LAGER-08, LAGER-10, LAGER-13, LAGER-14, LAGER-38, LAGER-52, LAGER-62, and LAGER-87 (Table 1). Line LAGER-08 was found to be the most resistant in that study, followed closely by EMGOPA-316 and LAGER-10. Of these 10 genotypes most resistant to the Uberaba isolate, four (EMGOPA-316, LAGER-08, LAGER-10, and LAGER-52) were also the most resistant when inoculated with the Jataí isolate, which is a more aggressive isolate (Juliatti et al., 2014) in the greenhouse study (Table 1). The genotypes LAGER-62 and LAGER-87 were also fairly resistant when inoculated with the Jatai isolate, and were the second most-resistant group; however, the other four genotypes that showed good resistance to the Uberaba isolate, were highly susceptible when challenged with the Jataí isolate.

Genetics and Molecular Research 15 (4): gmr15049061 
Although the main focus of this study was to characterize host resistance, variability between two pathogen isolates was also observed. The variability of S. sclerotiorum isolates has been previously characterized relative to the infectious process of the pathogen in host plants (Lumsden, 1979; Williams et al., 2011). Possible differences between isolates include their ability to respond to specific environmental factors, variable levels of oxalic acid production, type and quantity of secreted plant-cell-wall-degrading enzymes, and variation in secreted effector proteins. Other studies have also found that the majority of the cultivars evaluated in S. sclerotiorum disease screening showed variability in their susceptibility to the pathogen (Garcia and Juliatti, 2012).

In the present study, the most susceptible genotype was M7908RR, with an average lesion length induced by $S$. sclerotiorum of $5.46 \mathrm{~cm}$ (Uberaba isolate) and $5.54 \mathrm{~cm}$ (Jataí isolate). The M7908RR genotype was also among the most susceptible group identified in the study of Juliatti et al. (2013).

\section{Growth chamber experiment}

After we determined that the isolate from Jataí was statistically more aggressive than that from Uberaba, a second experiment was conducted, which involved inoculating the same genotypes with only the Jataí isolate, and then incubating in a controlled environment within a growth chamber $\left(20^{\circ} \pm 2{ }^{\circ} \mathrm{C}\right)$. Following inoculation with the Jataí isolate and a 5-day incubation period, the average length of lesions induced by S. sclerotiorum was $5.44 \mathrm{~cm}$ (Table 2).

Statistical analysis separated the genotypes into seven groups, a-g (Table 2). The most resistant genotypes were EMGOPA-316 and LAGER-10, with average lesion sizes of 0.20 and $1.60 \mathrm{~cm}$, respectively. The two genotypes in the next most resistant group were LAGER-45 and LAGER-11, with average lesion lengths of 1.94 and $2.70 \mathrm{~cm}$, respectively. Four genotypes formed the most susceptible group (Table 2): LAGER-25 $(7.62 \mathrm{~cm})$, LAGER-19 $(7.86 \mathrm{~cm})$, LAGER-36 $(7.92 \mathrm{~cm})$, and LAGER-29 $(8.44 \mathrm{~cm})$.

\section{Genetic parameters}

To ascertain the reliability of genotype selection based on desirable traits, such as disease resistance, it is important to determine some genetic parameters when evaluating the desired phenotypic characteristics (Cruz et al., 2012). For our data, the coefficient of genotypic determination $\left(\mathrm{h}^{2}\right)$ expressed phenotypic variability for mean lesion length $(\mathrm{cm})$. The phenotypic measurement can be used as an indicator of the genotypic grouping value (Ramalho et al., 2012) if the value is greater than 70\% (Cruz et al., 2012), which indicates that the phenotypic variability is predominantly of a genetic origin (assuming fixed effects and homozygous genotypes). The estimated value for $\mathrm{h}^{2}$ from the experiment conducted in the greenhouse with the Uberaba isolate was 76.74, with the Jataí isolate was 91.92, and the value from the joint analysis was 91.86 (Table 2). Estimated $\mathrm{h}^{2}$ from the experiment conducted in the growth chamber using the Jataí isolate was 94.79 (Table 1). The calculated $\mathrm{h}^{2}$ values suggest that the growth chamber environment contribution more to the evaluation of resistance than the greenhouse environment.

Another genetic parameter that can assist in the selection process is the ratio of the genetic variation coefficient to the variation coefficient $(\mathrm{CVg} / \mathrm{CVe})$, if this value is higher than 1.0 (Ramalho et al., 1993).

Genetics and Molecular Research 15 (4): gmr15049061 
Table 2. Average size of the lesion (cm) in soybean genotypes following inoculation with different isolates of Sclerotinia sclerotiorum and incubated under different environments.

\begin{tabular}{|c|c|c|c|c|}
\hline \multirow[t]{3}{*}{ Genotypes } & \multicolumn{4}{|c|}{ Average lesion size $(\mathrm{cm})^{\S}$} \\
\hline & \multicolumn{2}{|c|}{ Greenhousel } & \multicolumn{2}{|c|}{ Growth chamber $^{+}$} \\
\hline & Uberaba & Jataí & Genotypes & Jataí \\
\hline EMGOPA-316 & $1.36^{\mathrm{Aa}}$ & $1.50^{\mathrm{Aa}}$ & EMGOPA-316 & $0.20^{\mathrm{a}}$ \\
\hline $\begin{array}{l}\text { LAGER-05 } \\
\end{array}$ & $2.30^{\mathrm{Aa}}$ & $3.38^{\mathrm{Bc}}$ & LAGER-10 & $1.60^{\mathrm{a}}$ \\
\hline $\begin{array}{l}\text { LAGER-08 } \\
\end{array}$ & $1.28^{\mathrm{Aa}}$ & $2.06^{\mathrm{Aa}}$ & LAGER-11 & $2.70^{\mathrm{b}}$ \\
\hline $\begin{array}{l}\text { LAGER-10 } \\
\end{array}$ & $1.52^{\mathrm{Aa}}$ & $1.38^{\mathrm{Aa}}$ & LAGER-45 & $1.94^{\mathrm{b}}$ \\
\hline LAGER-13 & $2.24^{\mathrm{Aa}}$ & $3.58^{\mathrm{Bc}}$ & LAGER-05 & $3.68^{\mathrm{c}}$ \\
\hline LAGER-14 & $2.50^{\mathrm{Aa}}$ & $3.92^{\mathrm{Bc}}$ & LAGER-09 & $3.70^{\mathrm{c}}$ \\
\hline LAGER-38 & $1.98^{\mathrm{Aa}}$ & $4.16^{\mathrm{Bd}}$ & LAGER-14 & $3.70^{\mathrm{c}}$ \\
\hline LAGER-52 & $2.04^{\mathrm{Aa}}$ & $1.74^{\mathrm{Aa}}$ & LAGER-16 & $3.54^{\mathrm{c}}$ \\
\hline $\begin{array}{l}\text { LAGER-62 } \\
\end{array}$ & $2.24^{\mathrm{Aa}}$ & $2.76^{\mathrm{Ab}}$ & LAGER-18 & $3.74^{\mathrm{c}}$ \\
\hline LAGER-87 & $2.22^{\mathrm{Aa}}$ & $2.28^{\mathrm{Ab}}$ & LAGER-22 & $3.62^{\mathrm{c}}$ \\
\hline $\begin{array}{l}\text { LAGER-04 } \\
\end{array}$ & $3.10^{\mathrm{Ab}}$ & $3.54^{\mathrm{Ac}}$ & LAGER-24 & $3.80^{\mathrm{c}}$ \\
\hline $\begin{array}{l}\text { LAGER-06 } \\
\end{array}$ & $2.56^{\mathrm{Ab}}$ & $3.30^{\mathrm{Ac}}$ & LAGER-58 & $3.78^{\mathrm{c}}$ \\
\hline LAGER-07 & $3.10^{\mathrm{Ab}}$ & $3.78^{\mathrm{Ac}}$ & LAGER-60 & $3.82^{\mathrm{c}}$ \\
\hline $\begin{array}{l}\text { LAGER-09 } \\
\end{array}$ & $2.82^{\mathrm{Ab}}$ & $3.30^{\mathrm{Ac}}$ & LAGER-68 & $3.88^{\mathrm{c}}$ \\
\hline LAGER-11 & $2.72^{\mathrm{Ab}}$ & $2.56^{\mathrm{Ab}}$ & LAGER-78 & $3.98^{\mathrm{c}}$ \\
\hline LAGER-12 & $3.56^{\mathrm{Ab}}$ & $2.82^{\mathrm{Ab}}$ & LAGER-79 & $3.98^{\mathrm{c}}$ \\
\hline LAGER-15 & $2.86^{\mathrm{Ab}}$ & $3.64^{\mathrm{Ac}}$ & LAGER-81 & $3.90^{\mathrm{c}}$ \\
\hline LAGER-16 & $2.66^{\mathrm{Ab}}$ & $3.32^{\mathrm{Ac}}$ & LAGER-101 & $3.32^{\mathrm{c}}$ \\
\hline $\begin{array}{l}\text { LAGER-17 } \\
\text { - }\end{array}$ & $2.92^{\mathrm{Ab}}$ & $3.30^{\mathrm{Ac}}$ & LAGER-08 & $5.12^{\mathrm{d}}$ \\
\hline LAGER-18 & $3.02^{\mathrm{Ab}}$ & $3.52^{\mathrm{Ac}}$ & LAGER-26 & $4.52^{\mathrm{d}}$ \\
\hline LAGER-19 & $2.94^{\mathrm{Ab}}$ & $3.72^{\mathrm{Ac}}$ & LAGER-32 & $4.36^{\mathrm{d}}$ \\
\hline $\begin{array}{l}\text { LAGER-20 } \\
\text { - }\end{array}$ & $3.46^{\mathrm{Ab}}$ & $3.80^{\mathrm{Ac}}$ & LAGER-33 & $5.22^{\mathrm{d}}$ \\
\hline $\begin{array}{l}\text { LAGER-23 } \\
\end{array}$ & $3.52^{\mathrm{Ab}}$ & $4.16^{\mathrm{Ad}}$ & LAGER-40 & $4.36^{\mathrm{d}}$ \\
\hline LAGER-26 & $3.24^{\mathrm{Ab}}$ & $3.46^{\mathrm{Ac}}$ & LAGER-42 & $5.24^{\mathrm{d}}$ \\
\hline $\begin{array}{l}\text { LAGER-27 } \\
\end{array}$ & $3.46^{\mathrm{Ab}}$ & $5.24^{\mathrm{Be}}$ & LAGER-46 & $4.48^{\mathrm{d}}$ \\
\hline $\begin{array}{l}\text { LAGER-28 } \\
\text {. }\end{array}$ & $2.92^{\mathrm{Ab}}$ & $3.36^{\mathrm{Ac}}$ & LAGER-48 & $4.62^{\mathrm{d}}$ \\
\hline LAGER-29 & $2.88^{\mathrm{Ab}}$ & $3.02^{\mathrm{Ac}}$ & LAGER-49 & $4.54^{\mathrm{d}}$ \\
\hline $\begin{array}{l}\text { LAGER-30 } \\
\text { - }\end{array}$ & $2.96^{\mathrm{Ab}}$ & $3.32^{\mathrm{Ac}}$ & LAGER-50 & $4.32^{\mathrm{d}}$ \\
\hline LAGER-32 & $3.14^{\mathrm{Ab}}$ & $3.92^{\mathrm{Ac}}$ & LAGER-52 & $4.42^{\mathrm{d}}$ \\
\hline LAGER-33 & $2.64^{\mathrm{Ab}}$ & $2.42^{\mathrm{Ab}}$ & LAGER-57 & $4.58^{\mathrm{d}}$ \\
\hline LAGER-34 & $3.48^{\mathrm{Ab}}$ & $3.94^{\mathrm{Ac}}$ & LAGER-62 & $5.10^{\mathrm{d}}$ \\
\hline LAGER-35 & $3.10^{\mathrm{Ab}}$ & $3.68^{\mathrm{Ac}}$ & LAGER-63 & $4.72^{\mathrm{d}}$ \\
\hline LAGER-36 & $3.46^{\mathrm{Ab}}$ & $3.72^{\mathrm{Ac}}$ & LAGER-65 & $4.84^{\mathrm{d}}$ \\
\hline $\begin{array}{l}\text { LAGER-39 } \\
\text { - }\end{array}$ & $3.38^{\mathrm{Ab}}$ & $3.86^{\mathrm{Ac}}$ & LAGER-69 & $4.34^{\mathrm{d}}$ \\
\hline LAGER-53 & $3.22^{\mathrm{Ab}}$ & $3.60^{\mathrm{Ac}}$ & LAGER-73 & $4.28^{\mathrm{d}}$ \\
\hline $\begin{array}{l}\text { LAGER-54 } \\
\end{array}$ & $2.70^{\mathrm{Ab}}$ & $3.32^{\mathrm{Ac}}$ & LAGER-75 & $5.20^{\mathrm{d}}$ \\
\hline $\begin{array}{l}\text { LAGER-56 } \\
\end{array}$ & $2.60^{\mathrm{Ab}}$ & $3.68^{\mathrm{Bc}}$ & LAGER-76 & $4.70^{\mathrm{d}}$ \\
\hline LAGER-60 & $3.48^{\mathrm{Ab}}$ & $3.66^{\mathrm{Ac}}$ & LAGER-77 & $4.54^{\mathrm{d}}$ \\
\hline $\begin{array}{l}\text { LAGER-61 } \\
\end{array}$ & $3.18^{\mathrm{Ab}}$ & $3.42^{\mathrm{Ac}}$ & LAGER-80 & $4.34^{\mathrm{d}}$ \\
\hline LAGER-63 & $2.96^{\mathrm{Ab}}$ & $3.04^{\mathrm{Ac}}$ & LAGER-85 & $4.96^{\mathrm{d}}$ \\
\hline $\begin{array}{l}\text { LAGER-64 } \\
\end{array}$ & $3.54^{\mathrm{Ab}}$ & $3.94^{\mathrm{Ac}}$ & LAGER-92 & $4.68^{\mathrm{d}}$ \\
\hline LAGER-65 & $3.00^{\mathrm{Ab}}$ & $3.48^{\mathrm{Ac}}$ & LAGER-97 & $4.58^{\mathrm{d}}$ \\
\hline LAGER-66 & $3.46^{\mathrm{Ab}}$ & $3.80^{\mathrm{Ac}}$ & LAGER-98 & $4.90^{\mathrm{d}}$ \\
\hline $\begin{array}{l}\text { LAGER-67 } \\
\end{array}$ & $3.40^{\mathrm{Ab}}$ & $4.02^{\mathrm{Ac}}$ & LAGER-99 & $5.00^{\mathrm{d}}$ \\
\hline LAGER-73 & $3.08^{\mathrm{Ab}}$ & $3.14^{\mathrm{Ac}}$ & LAGER-103 & $5.18^{\mathrm{d}}$ \\
\hline LAGER-74 & $2.76^{\mathrm{Ab}}$ & $2.86^{\mathrm{Ab}}$ & LAGER-03 & $6.16^{\mathrm{e}}$ \\
\hline LAGER-75 & $2.82^{\mathrm{Ab}}$ & $2.84^{\mathrm{Ab}}$ & LAGER-04 & $5.52^{\circ}$ \\
\hline LAGER-76 & $3.22^{\mathrm{Ab}}$ & $3.40^{\mathrm{Ac}}$ & LAGER-12 & $5.42^{\mathrm{e}}$ \\
\hline LAGER-77 & $3.28^{\mathrm{Ab}}$ & $2.88^{\mathrm{Ab}}$ & LAGER-17 & $6.08^{\mathrm{e}}$ \\
\hline LAGER-78 & $2.94^{\mathrm{Ab}}$ & $4.56^{\mathrm{Bd}}$ & LAGER-20 & $5.76^{\mathrm{e}}$ \\
\hline $\begin{array}{l}\text { LAGER-81 } \\
\end{array}$ & $2.80^{\mathrm{Ab}}$ & $2.98^{\mathrm{Ab}}$ & LAGER-23 & $5.70^{\mathrm{e}}$ \\
\hline LAGER-83 & $3.12^{\mathrm{Ab}}$ & $3.38^{\mathrm{Ac}}$ & LAGER-27 & $6.26^{\mathrm{e}}$ \\
\hline $\begin{array}{l}\text { LAGER-85 } \\
\end{array}$ & $3.26^{\mathrm{Ab}}$ & $4.20^{\mathrm{Ad}}$ & LAGER-28 & $6.24^{\mathrm{e}}$ \\
\hline LAGER-86 & $3.16^{\mathrm{Ab}}$ & $3.76^{\mathrm{Ac}}$ & LAGER-31 & $6.42^{\mathrm{e}}$ \\
\hline LAGER-88 & $2.92^{\mathrm{Ab}}$ & $3.50^{\mathrm{Ac}}$ & LAGER-34 & $5.40^{\mathrm{e}}$ \\
\hline $\begin{array}{l}\text { LAGER-90 } \\
\end{array}$ & $2.82^{\mathrm{Ab}}$ & $3.40^{\mathrm{Ac}}$ & LAGER-35 & $5.38^{\mathrm{e}}$ \\
\hline LAGER-95 & $3.34^{\mathrm{Ab}}$ & $4.54^{\mathrm{Bd}}$ & LAGER-37 & $6.02^{\mathrm{e}}$ \\
\hline
\end{tabular}

Continued on next page

Genetics and Molecular Research 15 (4): gmr15049061 
Table 2. Continued.

\begin{tabular}{|c|c|c|c|c|}
\hline \multirow{3}{*}{ Genotypes } & \multicolumn{4}{|c|}{ Average lesion size $(\mathrm{cm})^{\S}$} \\
\hline & \multicolumn{2}{|c|}{ Greenhousel $^{l}$} & \multicolumn{2}{|c|}{ Growth chamber $^{\ddagger}$} \\
\hline & Uberaba & Jataí & Genotypes & Jataí \\
\hline LAGER-96 & $2.90^{\mathrm{Ab}}$ & $2.88^{\mathrm{Ab}}$ & LAGER-38 & $5.32^{\mathrm{c}}$ \\
\hline LAGER-97 & $3.02^{\mathrm{Ab}}$ & $3.38^{\mathrm{Ac}}$ & LAGER-41 & $5.78^{\mathrm{c}}$ \\
\hline LAGER-99 & $3.08^{\mathrm{Ab}}$ & $3.44^{\mathrm{Ac}}$ & LAGER-47 & $5.86^{\circ}$ \\
\hline LAGER-101 & $3.44^{\mathrm{Ab}}$ & $3.70^{\mathrm{Ac}}$ & LAGER-51 & $5.74^{\circ}$ \\
\hline LAGER-102 & $2.60^{\mathrm{Ab}}$ & $3.18^{\mathrm{Ac}}$ & LAGER-53 & $5.98^{\circ}$ \\
\hline LAGER-103 & $3.02^{\mathrm{Ab}}$ & $3.14^{\mathrm{Ac}}$ & LAGER-54 & $5.36^{\mathrm{c}}$ \\
\hline LAGER-03 & $3.74^{\mathrm{Ac}}$ & $3.56^{\mathrm{Ac}}$ & LAGER-55 & $5.96^{\mathrm{c}}$ \\
\hline LAGER-21 & $4.24^{\mathrm{Ac}}$ & $4.58^{\mathrm{Ad}}$ & LAGER-59 & $5.52^{\mathrm{c}}$ \\
\hline LAGER-22 & $3.66^{\mathrm{Ac}}$ & $5.24^{\mathrm{Be}}$ & LAGER-66 & $5.92^{\mathrm{c}}$ \\
\hline LAGER-31 & $3.74^{\mathrm{Ac}}$ & $4.46^{\mathrm{Ad}}$ & LAGER-70 & $5.52^{\mathrm{c}}$ \\
\hline LAGER-40 & $4.08^{\mathrm{Ac}}$ & $4.82^{\mathrm{Ad}}$ & LAGER-71 & $5.82^{\circ}$ \\
\hline LAGER-43 & $3.94^{\mathrm{Ac}}$ & $3.94^{\mathrm{Ac}}$ & LAGER-72 & $5.44^{\circ}$ \\
\hline LAGER-47 & $3.84^{\mathrm{Ac}}$ & $3.90^{\mathrm{Ac}}$ & LAGER-74 & $5.98^{\circ}$ \\
\hline LAGER-49 & $3.86^{\mathrm{Ac}}$ & $3.94^{\mathrm{Ac}}$ & LAGER-82 & $6.26^{\mathrm{c}}$ \\
\hline LAGER-50 & $4.24^{\mathrm{Ac}}$ & $4.82^{\mathrm{Ad}}$ & LAGER-83 & $6.12^{\mathrm{c}}$ \\
\hline LAGER-51 & $3.74^{\mathrm{Ac}}$ & $4.26^{\mathrm{Ad}}$ & LAGER-84 & $5.48^{\circ}$ \\
\hline LAGER-55 & $3.64^{\mathrm{Ac}}$ & $3.64^{\mathrm{Ac}}$ & LAGER-86 & $5.56^{\circ}$ \\
\hline LAGER-57 & $4.20^{\mathrm{Ac}}$ & $6,04^{\mathrm{Be}}$ & LAGER-87 & $6.36^{\mathrm{c}}$ \\
\hline LAGER-58 & $4.38^{\mathrm{Ac}}$ & $4.54^{\mathrm{Ad}}$ & LAGER-88 & $6.22^{\mathrm{c}}$ \\
\hline LAGER-59 & $4.38^{\mathrm{Ac}}$ & $4.40^{\mathrm{Ad}}$ & LAGER-89 & $6.28^{\mathrm{c}}$ \\
\hline LAGER-69 & $4.22^{\mathrm{Ac}}$ & $4.84^{\mathrm{Ad}}$ & LAGER-90 & $6.02^{\mathrm{c}}$ \\
\hline LAGER-71 & $4.32^{\mathrm{Ac}}$ & $4.98^{\mathrm{Ae}}$ & LAGER-91 & $5.70^{\circ}$ \\
\hline LAGER-72 & $4.04^{\mathrm{Ac}}$ & $5.16^{\mathrm{Be}}$ & LAGER-93 & $5.96^{\mathrm{c}}$ \\
\hline LAGER-79 & $4.08^{\mathrm{Ac}}$ & $4.48^{\mathrm{Ad}}$ & LAGER-94 & $5.72^{\mathrm{c}}$ \\
\hline LAGER-80 & $3.70^{\mathrm{Ac}}$ & $3.92^{\mathrm{Ac}}$ & LAGER-102 & $5.40^{\circ}$ \\
\hline LAGER-82 & $4.42^{\mathrm{Ac}}$ & $5.12^{\mathrm{Ae}}$ & M7908RR & $6.60^{f}$ \\
\hline LAGER-84 & $3.68^{\mathrm{Ac}}$ & $3.64^{\mathrm{Ac}}$ & LAGER-06 & $6.52^{\mathrm{f}}$ \\
\hline LAGER-89 & $3.72^{\mathrm{Ac}}$ & $4.16^{\mathrm{Ad}}$ & LAGER-07 & $6.88^{1}$ \\
\hline LAGER-91 & $3.90^{\mathrm{Ac}}$ & $4.60^{\mathrm{Ad}}$ & LAGER-13 & $6.80^{1}$ \\
\hline LAGER-92 & $3.82^{\mathrm{Ac}}$ & $4.40^{\mathrm{Ad}}$ & LAGER-15 & $6.74^{t}$ \\
\hline LAGER-93 & $3.94^{\mathrm{Ac}}$ & $3.96^{\mathrm{Ac}}$ & LAGER-21 & $7.24^{t}$ \\
\hline LAGER-94 & $4.02^{\mathrm{Ac}}$ & $3.96^{\mathrm{Ac}}$ & LAGER-30 & $7.18^{t}$ \\
\hline LAGER-98 & $3.98^{\mathrm{Ac}}$ & $4.62^{\mathrm{Ad}}$ & LAGER-39 & $6.66^{t}$ \\
\hline LAGER-100 & $3.74^{\mathrm{Ac}}$ & $3.46^{\mathrm{Ac}}$ & LAGER-43 & $6.78^{\mathrm{f}}$ \\
\hline LAGER-24 & $4.80^{\mathrm{Ad}}$ & $5.14^{\mathrm{Ae}}$ & LAGER-44 & $7.08^{1}$ \\
\hline LAGER-25 & $4.90^{\mathrm{Ad}}$ & $5.48^{\mathrm{Ae}}$ & LAGER-56 & $6.54^{t}$ \\
\hline LAGER-37 & $4.80^{\mathrm{Ad}}$ & $5.10^{\mathrm{Ae}}$ & LAGER-61 & $6.94^{\mathrm{t}}$ \\
\hline LAGER-41 & $4.70^{\mathrm{Ad}}$ & $4.34^{\mathrm{Ad}}$ & LAGER-64 & $7.42^{\mathrm{f}}$ \\
\hline LAGER-42 & $4.60^{\mathrm{Ad}}$ & $4.84^{\mathrm{Ad}}$ & LAGER-67 & $6.58^{4}$ \\
\hline LAGER-44 & $5.22^{\mathrm{Ad}}$ & $5.60^{\mathrm{Ae}}$ & LAGER-95 & $7.14^{t}$ \\
\hline LAGER-45 & $4.72^{\mathrm{Ad}}$ & $4.42^{\mathrm{Ad}}$ & LAGER-96 & $7.00^{\mathrm{f}}$ \\
\hline LAGER-46 & $4.48^{\mathrm{Ad}}$ & $5.08^{\mathrm{Ae}}$ & LAGER-100 & $6.66^{1}$ \\
\hline LAGER-68 & $5.20^{\mathrm{Ad}}$ & $5.66^{\mathrm{Ae}}$ & LAGER-19 & $7.86^{8}$ \\
\hline LAGER-70 & $4.96^{\mathrm{Ad}}$ & $5.48^{\mathrm{Ae}}$ & LAGER-25 & $7.62 \mathrm{~g}$ \\
\hline LAGER-48 & $5.18^{\mathrm{Ad}}$ & $5.50^{\mathrm{Ae}}$ & LAGER-29 & $8.44 \mathrm{~s}$ \\
\hline M7908RR & $5.46^{\mathrm{Ae}}$ & $5.54^{\mathrm{Ae}}$ & LAGER-36 & $7.92^{\mathrm{g}}$ \\
\hline \multicolumn{5}{|c|}{ Individual analysis } \\
\hline Average & $3.42^{\mathrm{b}}$ & $3.86^{\mathrm{a}}$ & \multicolumn{2}{|c|}{5.44} \\
\hline CV (\%) & 26.29 & 14.97 & \multicolumn{2}{|c|}{11.91} \\
\hline $\mathrm{h}^{2}$ & 76.74 & 91.92 & \multicolumn{2}{|c|}{94.79} \\
\hline $\mathrm{CVg} / \mathrm{CVe}$ & 0.82 & 1.51 & \multicolumn{2}{|c|}{1.90} \\
\hline \multicolumn{5}{|l|}{ Joint analysis } \\
\hline Average & \multicolumn{2}{|c|}{3.64} & & \\
\hline CV (\%) & \multicolumn{2}{|c|}{20.77} & & \\
\hline $\mathrm{h}^{2}$ & \multicolumn{2}{|c|}{91.86} & & \\
\hline CVg/Cve & \multicolumn{2}{|c|}{1.06} & & \\
\hline
\end{tabular}

${ }^{\S}$ Average values followed by the same letter in a column do not differ statistically by the Scott-Knott test $(\mathrm{P}<$ $0.05) ; \mathrm{h}^{2}$ : coefficient of genotypic determination; $\mathrm{CVg} / \mathrm{CVe}$ : ratio of the genetic variation coefficient to the variation coefficient; environmental analysis of the experiments conducted in the greenhouse and growth chamber were independent of each other. Joint analysis of the average lesion size evaluated in greenhouse conditions inoculating soybean plants with isolates from Uberaba and Jataí, with five replicates from each experiment; 'simple analysis of the average lesion size evaluated under growth chamber conditions following inoculation of soybean plants with the isolate from Jataí, with five replicates.

Genetics and Molecular Research 15 (4): gmr15049061 
The estimates of $\mathrm{CVg} / \mathrm{CVe}$ from the experiment conducted in the greenhouse was 0.82 (isolate from Uberaba), 1.51 (isolate from Jataí), and 1.06 (joint analysis of both isolates). The growth chamber experiment (isolate from Jataí) gave the best $\mathrm{CVg} / \mathrm{CVe}$ ratio, at 1.90. Based on this genetic parameter, the experiment conducted in the growth chamber provided the most reliable data to assess resistance to $S$. sclerotiorum.

\section{Genetic diversity between soybean genotypes based on their resistance to $S$. sclerotiorum by multivariate analysis}

We analyzed data describing the average lesion length by a multivariate analysis of genetic diversity using UPGMA. A dendrogram depicting relatedness (Figure 1) was then generated for the experiments conducted in the greenhouse and growth chamber. This graphical representation resulted from the dissimilarity of the genotypes based on disease susceptibility as measured by lesion length in $\mathrm{cm}$.

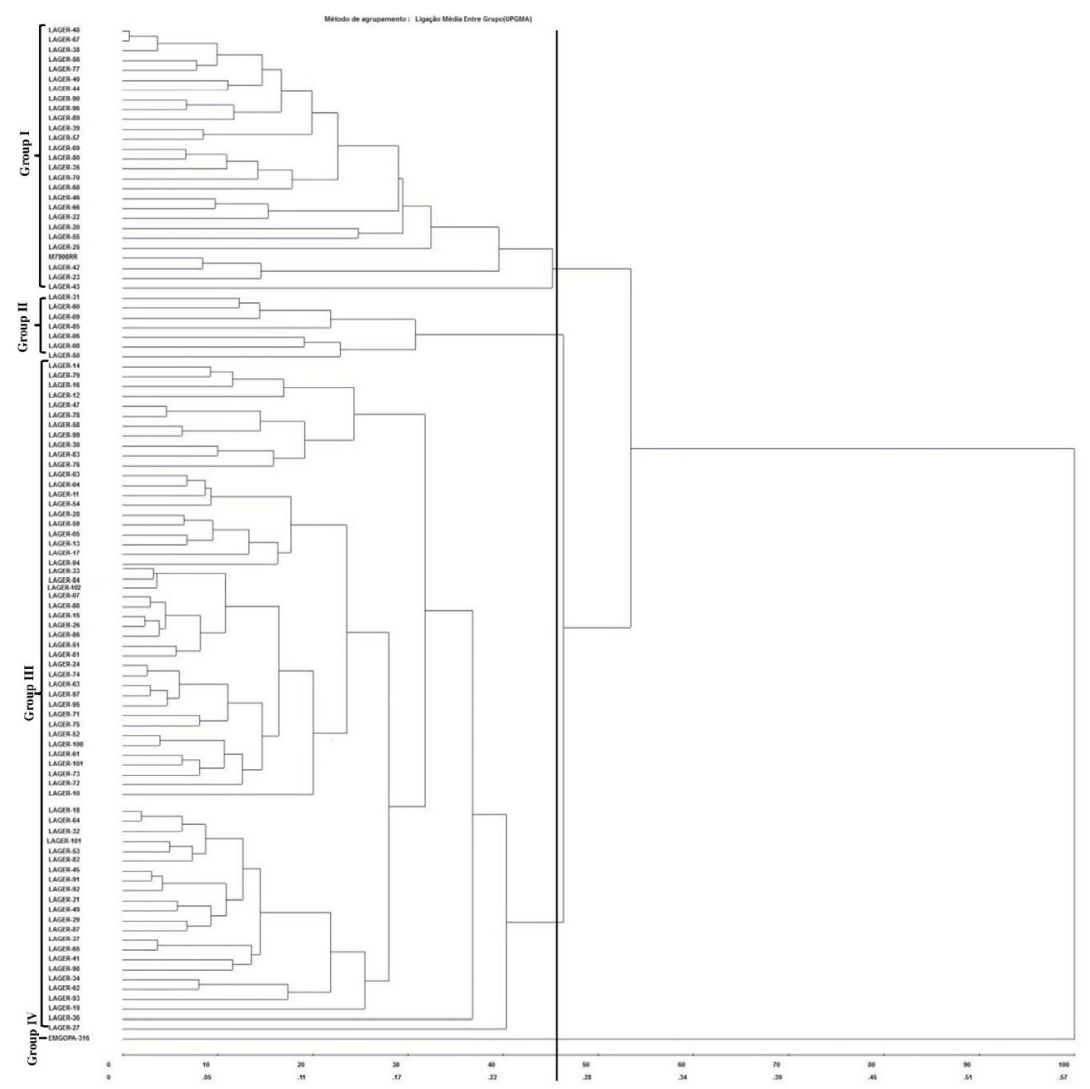

Figure 1. Dendrogram illustrating the analysis of 103 soybean genotypes by the unweighted pair group method with arithmetic mean (UPGMA). This graphical representation was obtained with the Euclidean distance from the dissimilarity matrix of the supplement of simple coincidence of evaluations of the lesion size of both isolates of Sclerotinia sclerotiorum by the evaluations carried out in a greenhouse (isolates from Uberaba and Jataí) and a growth chamber (isolate from Jataí). Cophenetic correlation coefficient $(\mathrm{r})=0.7404$.

Genetics and Molecular Research 15 (4): gmr15049061 
The cophenetic correlation coefficient (a value indicative of how well a dendrogram agrees with the dissimilarities between the genotypes) was calculated as 0.7404 . Barroso and Artes (2003) indicated that a cophenetic correlation coefficient of 0.70 or higher is evidence of a reliable dendrogram of genetic distances between the genotypes and the original matrix. A line was drawn on the dendrogram at $47 \%$ dissimilarity in a subjective manner after verifying points of high-level change in the graphical representation (Cruz et al., 2011). This arbitrary cut at $47 \%$ dissimilarity divided the soybean genotypes into four major groups, as depicted in Figure 1. It is clear that the genotype EMGOPA-316 was far superior in terms of resistance, as it stood out as an outlier of the dataset, and was the sole member of its group (Figure 1).

The Tocher method is also used to group genotypes based on phenotypic diversity (Rao, 1962). Using the same disease lesion phenotypic data that was used in the UPGMA method (Figure 1), the Tocher method generated five groups (Table 3). These were not as evenly divided as those generated using the UPGMA method, as there was one very large group containing 92 members (of 103), and four very small groups consisting of only seven, two, or one member. Interestingly, the Tocher method also separated the genotype EMGOPA-316 into its own, single member group.

Table 3. Grouping of 103 soybean genotypes by the Tocher optimization method using Euclidian distance, which was used as the genetic distance. This was obtained from data on average lesion size $(\mathrm{cm})$ following inoculation with different isolates of Sclerotinia sclerotiorum evaluated in different incubation environments (greenhouse and growth chamber).

\begin{tabular}{l|l}
\hline Group & Genotypes \\
\hline 1 & LAGER-03, LAGER-04, LAGER-05, LAGER-06, LAGER-07, LAGER-09, LAGER-10, LAGER-11, LAGER-12, \\
& LAGER-13, LAGER-14, LAGER-15, LAGER-16, LAGER-17, LAGER-18, LAGER-19, LAGER-20, LAGER-21, \\
& LAGER-22, LAGER-23, LAGER-24, LAGER-26, LAGER-27, LAGER-28, LAGER-29, LAGER-30, LAGER-31, \\
& LAGER-32, LAGER-33, LAGER-34, LAGER-35, LAGER-36, LAGER-37, LAGER-38, LAGER-39, LAGER-40, \\
& LAGER-41, LAGER-42, LAGER-43, LAGER-46, LAGER-47, LAGER-49, LAGER-50, LAGER-51, LAGER-53, \\
& LAGER-54, LAGER-55, LAGER-56, LAGER-58, LAGER-59, LAGER-60, LAGER-61, LAGER-62, LAGER-63, \\
& LAGER-64, LAGER-65, LAGER-66, LAGER-67, LAGER-69, LAGER-71, LAGER-72, LAGER-73, LAGER-74, \\
& LAGER-75, LAGER-76, LAGER-77, LAGER-78, LAGER-79, LAGER-80, LAGER-81, LAGER-82, LAGER-83, \\
& LAGER-84, LAGER-85, LAGER-86, LAGER-87, LAGER-88, LAGER-89, LAGER-90, LAGER-91, LAGER-92, \\
& LAGER-93, LAGER-94, LAGER-95, LAGER-96, LAGER-97, LAGER-98, LAGER-99, LAGER-100, LAGER-101, \\
& LAGER-102, LAGER-103 \\
\hline 2 & M7908RR, LAGER-25, LAGER-44, LAGER-48, LAGER-57, LAGER-68, LAGER-70 \\
\hline 3 & LAGER-08, LAGER-52 \\
\hline 5 & EMGOPA-316 \\
\hline
\end{tabular}

Vogt et al. (2012) evaluated the resistance of 17 sunflower cultivars to white mold and verified the presence of divergence and the formation of three distinct groups. Those authors also applied the multivariate analysis of UPGMA and the Tocher optimization method and canonical variables. However, in the majority of soybean studies, both analytical methods have been applied. Arriel et al. (2006) suggested that the Tocher optimization method can be used to supplement the UPGMA method.

Although identification of enhanced resistance to $S$. sclerotiorum in soybean might not fully prevent loss in yield (Hoffman et al., 1998), any improvement in resistance, or delay in disease progression, might make the difference between economic lost or profit. One such soybean genotype, which is looking promising for incorporation in a breeding program of S. sclerotiorum resistance, is EMGOPA-316. This genotype was at the top or near to the top of the list of resistance in both studies reported here, as well as in other published studies 
(Juliatti et al., 2013, 2014). The EMGOPA-316 genotype also showed good resistance to $S$. sclerotiorum under field conditions, in which the average lesion size was $2.75 \mathrm{~cm}$ (Juliatti et al., 2013). The most susceptible genotype identified in the present studies was LAGER-29, suggesting that this genotype could serve as a good susceptible control. The statistical analyses conducted on these datasets determined that the evaluation of soybean genotype resistance could be reliably conducted under our conditions in a growth chamber and using the Jataí isolate. In order to perform studies on the host resistance of soybean genotypes to $S$. sclerotiorum, the effect of environmental conditions on fungal infection should be considered and aggressive isolates should be used.

\title{
Conflicts of interest
}

The authors declare no conflict of interest.

\section{ACKNOWLEDGMENTS}

\author{
Research supported by FAPEMIG, CNPq and CAPES.
}

\section{REFERENCES}

Arriel NHC, Di Mauro AO, Di Mauro SMZ, Bakke AO, et al. (2006). Técnicas multivariadas na determinação da diversidade genética em gergelim usando marcadores RAPD. Pesqui. Agropecu. Bras. 45: 801-809. http://dx.doi. org $/ 10.1590 / \mathrm{S} 0100-204 \mathrm{X} 2006000500012$

Barroso LP and Artes T (2003). Análise multivariada. Lavras: UFLA.

Bastien M, Sonah M and Belzil F (2014). Genome wide association mapping of Sclerotinia sclerotiorum resistance in soybean with a genotyping-by-sequencing approach. Plant Genome 7: 1-13. http://dx.doi.org/10.3835/ plantgenome2013.10.0030

Chaves GM (1964). Estudos sobre Sclerotinia sclerotiorum (Lib.) de Bary. Experientiae. 4: 81.

Cruz CD (2013). GENES - a software package for analysis in experimental statistics and quantitative genetics. Acta Sci. Agron. 35: 271-276. http://dx.doi.org/10.4025/actasciagron.v35i3.21251

Cruz CD, Ferreira FM and Pessoni LA (2011). Biometria aplicada ao estudo da diversidade genética. Suprema, Visconde do Rio Branco.

Cruz CD, Regazzi AJ and Carneiro PCS (2012). Modelos biométricos aplicados ao melhoramento genético. UFV, Viçosa.

Cunha WG, Tinoco MLP, Pancoti HL, Ribeiro RE, et al. (2010). High resistance to Sclerotinia sclerotiorum in transgenic soybean plants transformed to express and oxalate decarboxylase gene. Plant Pathol. 59: 654-660. http://dx.doi. org $/ 10.1111 / \mathrm{j} .1365-3059.2010 .02279 . \mathrm{x}$

Furlan SH (2015). Mofo branco. In: Lemes EM, Castro LHS and Assis RT. Doenças da soja - Melhoramento genético e técnicas de manejo. Campinas: Editora Millennium. 53-72.

Garcia RA and Juliatti FC (2012). Avaliação da resistência da soja a Sclerotinia sclerotiorum em diferentes estádios fenológicos e períodos de exposição ao inóculo. Trop. Plant Pathol. 37: 196-203. http://dx.doi.org/10.1590/S1982$\underline{56762012000300006}$

Henning AA (2004). Patologia e tratamento de sementes: noções gerais. Londrina: Embrapa Soybean, 51p. (Embrapa Soybean. Documents $\cdots: 235$.

Hoffman DD, Hartman GL, Mueller DS, Leitz RA, et al. (1998). Yield and seed quality of soybean cultivars infected with Sclerotinia sclerotiorum. Plant Dis. 82: 826-829. http://dx.doi.org/10.1094/PDIS.1998.82.7.826

Juliatti FC and Juliatti FCA (2010). Podridão branca da haste da soja: manejo e uso de fungicidas em busca da sustentabilidade nos sistemas de produção. Uberlândia: Composer.

Juliatti FC, Caires AM, Juliatti BCM, Borin MR, et al. (2013). Reação de genótipos de soja transgênicos e convencionais à podridão branca da haste. Biosci. J. 29: 921-931.

Juliatti FC, Sagata E, Jaccoud Filho DS and Juliatti BCM (2014). Métodos de inoculação e avaliação da resistência de genótipos de soja à Sclerotinia sclerotiorum. Biosci. J. 30: 958-968.

Genetics and Molecular Research 15 (4): gmr15049061 
Juliatti FC, Figueiró AA, Garcia RÁ, Santos JB, et al. (2015). Sclerotinia sclerotiorum e mofo branco: estudos básicos e aplicados. Ver. Anual de Patol. Plantas 23: 159-194.

Kim HS, Hartman GL, Manandhar JB, Graf GL, et al. (2000). Reaction of soybean cultivars to sclerotia stem rot in field, greenhouse, and laboratory evaluations. Crop Sci. 40: 665-669. http://dx.doi.org/10.2135/cropsci2000.403665x

Lumsden RD (1979). Histology and physiology of pathogenesis in plant diseases caused by Sclerotinia sclerotiorum. Phytopathology 69: 890-895. http://dx.doi.org/10.1094/Phyto-69-890

Petzoldt R and Dickson MH (1996). Straw test for resistance to white mold in beans. Annu. Rep. Bean Improv. Coop. 39: 142-143.

Ramalho MAP, Santos JB and Zimmermann MJO (1993). Genética quantitativa em plantas autógamas: aplicações ao melhoramento do feijoeiro. UFG, Goiânia.

Ramalho MAP, Abreu ÂFB, Santos JB and Nunes JAR (2012). Aplicações da genética quantitativa no melhoramento de plantas autógamas. UFLA, Lavras.

Rao RC (1962). Advanced statistical methods in biometric research. New York: John Wiley.

Singh PS and Terán H (2008). Evolution of screening methods for detection of physiological resistance to White mold in common bean. Аnпu. Rep. Bean Improv. Coop. 51: 40-41.

Vogt GA, Balbinot AA, Junior. and Souza AM (2012). Divergência fenotípica em genótipos de girassol. Rev. Cienc. Agrovet. 11: 26-34.

Williams B, Kabbage M, Kim HJ, Britt R, et al. (2011). Tipping the balance: Sclerotinia sclerotiorum secreted oxalic acid suppresses host defenses by manipulating the host redox environment. PLoS Pathog. 7: e1002107. http://dx.doi. org/10.1371/journal.ppat.1002107

Genetics and Molecular Research 15 (4): gmr15049061 